\title{
KEBIASAAN KONSUMSI IKAN LAUT, TINGKAT KONSUMSI, STATUS GIZI, DAN PRESTASI BELAJAR SISWA SEKOLAH DASAR DI DAERAH PANTAI DAN BUKAN PANTAI
}

\author{
Marine Fish Consumption Habits, Consumption Level, Nutritional \\ Status, and Learning Achievement of Elementary School Children in \\ Coastal and Non Coastal Areas
}

\author{
Farida $^{1}$, Katrin Roosita ${ }^{2}$
}

${ }^{1}$ Prodi Ilmu Gizi, Fakultas Ilmu-ilmu Kesehatan (FIKes), Universitas Jenderal Soedirman, Purwokerto 53123 Email: farida.140991@gmail.com

${ }^{2}$ Departemen Gizi Masyarakat, Fakultas Ekologi Manusia (FEMA), Institut Pertanian Bogor, Bogor 16680 Email: kroosita@yahoo.com

\begin{abstract}
Marine fish is a source of animal protein that is important for the physical growth and mental development of school children. The purpose of this study was to study the consumption habits of marine fish in primary school children in coastal areas and not beaches, the level of adequacy of energy and protein, nutritional status, and learning achievement. The study was conducted in June-July 2012 with a cross-sectional design and was located in two elementary schools namely SD Negeri 03 Karang City, Pasaran Island, Lampung (representing coastal areas), and Ciaruteun Ilir 01 Public Elementary School, Ciaruteun Ilir, Bogor (as an area not beach). The research subjects were grade 5 from two primary schools, each of which amounted to 27 students, bringing the total subjects to 54 students. The results showed that there were significant differences between coastal and non-coastal areas, indicated by the frequency and amount of consumption of marine fish in coastal areas higher than non-coastal areas, as well as the level of adequacy of energy and protein. Nutritional status and learning achievement in coastal areas are also better than non-coastal areas. The frequency of consumption of marine fish correlates with the level of consumption of energy and protein. The level of adequacy of energy and protein correlates with nutritional status of BMI / U and LILA. The level of energy sufficiency also correlates with learning achievement.
\end{abstract}

Keywords: coastal and non coastal areas, marine fish consumption habit, energy and protein consumption level, nutritional status, learning achievement.

\section{ABSTRAK}

Ikan laut adalah sumber protein hewani yang penting untuk pertumbuhan fisik dan perkembangan mental anak sekolah. Tujuan penelitian ini untuk mempelajari kebiasaan konsumsi ikan laut pada anak sekolah dasar di daerah pantai dan bukan pantai, tingkat kecukupan energi dan protein, status gizi, dan prestasi belajarnya. Penelitian dilakukan pada bulan Juni-Juli 2012 dengan desain cross sectional dan berlokasi di dua sekolah dasar yaitu SD Negeri 03 Kota Karang, Pulau Pasaran, Lampung (mewakili daerah pantai), dan SD Negeri Ciaruteun Ilir 01, Ciaruteun Ilir, Bogor (sebagai daerah bukan pantai). Subyek penelitian adalah kelas 5 dari dua sekolah dasar, masing-masing berjumlah 27 siswa, sehingga total subyek 54 siswa. Hasil penelitian menunjukkan terdapat perbedaan signifikan antara daerah pantai dan bukan pantai, ditunjukkan dengan frekuensi dan jumlah konsumsi ikan laut di daerah pantai lebih tinggi dibanding daerah bukan pantai, demikian pula dengan tingkat kecukupan energi dan protein. Status gizi dan prestasi belajar di daerah pantai juga lebih baik dibanding daerah bukan pantai. Frekuensi konsumsi ikan laut berkorelasi dengan tingkat konsumsi energi dan protein. Tingkat kecukupan energi dan protein berkorelasi dengan status gizi IMT/U dan LILA. Tingkat kecukupan energi juga berkorelasi dengan prestasi belajar. 
Kata Kunci: pantai dan bukan pantai, kebiasaan konsumsi ikan laut, tingkat kecukupan energi dan protein, status gizi, prestasi belajar

\section{PENDAHULUAN}

Kualitas tumbuh kembang pada anak usia sekolah perlu mendapat perhatian khusus karena pada rentang usia tersebut terkait erat dengan perubahan kognitif, emosional, dan hormonal (Soekarti et al., 2011). Banyak faktor yang mempengaruhi kualitas tumbuh kembang anak usia sekolah, salah satunya adalah pemberian gizi dengan kualitas dan kuantitas yang tepat. Gizi dengan kualitas dan kuantitas yang tepat hanya dapat diperoleh dengan memilih bahan pangan yang tepat dan dalam porsi yang tepat pula (Vizuete et al., 2009).

Ikan merupakan salah bahan pangan yang bermutu gizi tinggi. Daging ikan mengandung protein 18,0-30,0 \%, lemak 0,1-2,2 \%, dan sisanya merupakan vitamin terutama larut lemak, dan mineral seperti iodium, seng, dan besi (Afrianto dan Liviawaty 1989). Nilai biologis proteinnya yang mencapai $90 \%$ membuat ikan berkontribusi besar bagi protein tubuh bila dikonsumsi (Suhartini dan Hidayat 2005).
Meskipun demikian, kandungan gizi tiap-tiap jenis ikan berbeda, terutama antara ikan laut (air asin) dan ikan air tawar. Ikan laut banyak mengandung sejumlah asam lemak tak jenuh omega-3 (Fernandez et al., 1999; Nurk et al., 2007), yang diketahui memiliki turunan asam dokoheksanoat (DHA) dan asam eikosapentanoat (EPA) yang sangat berperan dalam perkembangan saraf, otak, dan penglihatan. Dengan demikian konsumsi ikan laut tidak hanya berfungsi menjaga kesehatan fisik tetapi juga mendukung perkembangan kognitif (Almatsier, 2004; Etschmann et al., 2007; Oken et al., 2008).

Masyarakat pantai adalah sekelompok orang yang menetap di daerah pantai sedangkan masyarakat bukan pantai adalah sekelompok orang yang tinggal di daerah yang jauh dari pantai, baik di daerah dataran rendah maupun dataran tinggi. Kondisi geografis yang dekat dengan laut menyebabkan ketersediaan ikan laut masyarakat pantai lebih besar dibanding masyarakat yang bukan pantai. 
J. Gipas, November 2018, Volume 2 Nomor 2

ISSN 2599-0152 eISSn 2599-2465

http://jos.unsoed.ac.id/index.php/jgps

Aksesnya untuk memperoleh ikan laut lebih mudah, sehingga kebiasaan konsumsi pangan masyarakat pantai lebih didominasi oleh pangan berasal dari laut (Verbeke dan Vackier, 2005; Oktari, 2008). Sebaliknya, mereka yang tinggal jauh dari pantai lebih sering mengonsumsi makanan yang berasal dari tumbuh-tumbuhan atau pangan hewani yang bukan dari laut, misalnya telur, daging, dan ikan dari jenis ikan air tawar atau tambak (Widiamurti, 1998).

Kondisi lingkungan yang berbeda menyebabkan kebiasaan konsumsi pangan berbeda (Verbeke dan Vackier 2005). Kebiasaan konsumsi pangan yang berbeda menjadikan tingkat konsumsi zat gizinya berbeda, demikian pula status gizi juga tidak sama. Status gizi pada anak usia sekolah akan mempengaruhi kondisi kesehatannya, yang selanjutnya berdampak pada prestasi belajarnya (Widiamurti, 1998; Suryabrata, 2005). Karena itu penelitian bertujuan untuk mengetahui kebiasaan konsumsi ikan laut di daerah pantai dan bukan pantai, hubungannya dengan tingkat konsumsi energi dan protein, status gizi, dan prestasi belajar pada siswa sekolah dasar.

\section{METODE}

\section{Desain, Waktu, dan Tempat}

Desain yang digunakan pada penelitian ini adalah cross sectional. Penelitian dilakukan pada bulan JuniJuli 2012 bertempat di SDN 03 Kota Karang, Pulau Pasaran, Lampung dan SDN Ciaruteun Ilir 01, Cibungbulang, Bogor.

\section{Jumlah dan Cara Penarikan Contoh}

$$
\begin{aligned}
& \text { Pemilihan lokasi dilakukan } \\
& \text { secara purposive dengan } \\
& \text { mempertimbangkan hasil observasi } \\
& \text { yang dilakukan sebelumnya yaitu } \\
& \text { kondisi ekologis dan geografis yang } \\
& \text { berbeda pada dua daerah. Pulau } \\
& \text { Pasaran sebagai daerah yang } \\
& \text { mewakili wilayah pantai memiliki } \\
& \text { kondisi geografis berupa sebuah } \\
& \text { daratan di tengah laut (Teluk } \\
& \text { Lampung), sedangkan Desa }
\end{aligned}
$$
Ciaruteun Ilir adalah daratan yang terletak pada ketinggian 320 meter di atas permukaan laut. Subyek penelitian adalah siswa sekolah dasar kelas 5 dari dua SD yaitu SDN 03 Kota Karang yang mewakili daerah pantai dan SDN Ciaruteun Ilir 01 yang mewakili daerah bukan pantai. 
Total subyek 54 siswa yang terdiri dari 27 siswa SDN 03 Kota Karang dan 27 siswa SDN Ciaruteun Ilir 01. Kriteria pemilihan siswa kelas 5 didasarkan pada tahapan usia ini yang telah memiliki kemampuan cukup untuk dapat diwawancara atau dimintai keterangan. Kriteria inklusi dalam penelitian ini adalah hadir dan bersedia diwawancara selama hari pengambilan data, mampu memahami perintah dengan baik, mampu berbahasa Indonesia dengan baik, mampu mengingat, dan mampu menulis serta menghitung dengan baik. Kriteria eksklusinya adalah tidak hadir pada salah satu hari atau selama hari pengambilan data, memiliki gangguan pendengaran, penglihatan, atau ingatan, serta tidak mampu menulis dan menghitung.

Jenis dan Cara Pengumpulan Data

Data yang dikumpulkan meliputi data primer dan data sekunder. Data primer terdiri dari karakteristik siswa, karakteristik keluarga, kebiasaan konsumsi ikan laut siswa, konsumsi pangan siswa, dan status gizi siswa. Data karakteristik siswa diperoleh menggunakan kuesioner dengan cara diisi langsung oleh siswa. Data karakteristik keluarga diperoleh menggunakan kuesioner yang diisi langsung oleh orang tua siswa. Kebiasaan konsumsi ikan laut siswa diperoleh menggunakan food frequency questionaire (FFQ) dengan cara wawancara langsung terhadap siswa. Konsumsi pangan siswa diperoleh menggunakan food recall 2x24 jam dengan cara wawancara langsung terhadap siswa selama dua hari berturut-turut pada hari sekolah. Pengukuran status gizi dilakukan menggunakan metode antropometri. Tinggi badan diperoleh dengan cara mengukur langsung tinggi badan siswa menggunakan microtoise, berat badan diukur langsung menggunakan timbangan injak digital, dan lingkar lengan atas (LILA) diukur menggunakan pita LILA.

Data sekunder meliputi ratarata nilai hasil ulangan harian dan ulangan umum semester (UUS) siswa untuk mata pelajaran yang diajarkan dan diujikan secara nasional (Matematika, Bahasa Indonesia, dan IPA), dan profil sekolah. Hasil ulangan harian, UUS, dan profil sekolah diperoleh dengan melihat rekapan hasil ulangan harian 
dan hasil UUS siswa yang dimiliki oleh guru, menanyakan langsung pada pihak sekolah dan melihat data administrasi sekolah.

\section{Analisis Data}

Data dianalisis menggunakan statistik deskriptif dan inferensia dengan program software Microsoft Excel 2007 dan SPSS for Windows versi 16.0. Statistik deskriptif meliputi rataan, simpangan baku, nilai maksimum, dan nilai minimum. Statistik inferensia yang digunakan meliputi uji beda $t$-test, uji korelasi Pearson, dan uji korelasi Spearman.

Kebiasaan konsumsi ikan laut siswa dilihat secara kuantitatif melalui frekuensi konsumsi ikan laut per minggu yang dikategorikan menurut Camelia (2002) menjadi jarang $(<1 \mathrm{x} /$ minggu $)$, kadang $(1-3 \mathrm{x} /$ minggu), sering (4-6x/ minggu), dan sering sekali ( $\geq 7 \mathrm{x} /$ minggu).

Variabel konsumsi pangan diolah menggunakan Daftar Komposisi Bahan Makanan (DKBM) (tahun berapa??). Angka kecukupan gizi yang digunakan mengacu pada Widya Karya Nasional Pangan dan Gizi 2004 (WKNPG, 2004). Pengkategorian tingkat kecukupan gizi didasarkan pada Depkes (1996) yaitu dikatakan defisit tingkat berat jika $<70 \%$ AKG, defisit tingkat sedang jika tingkat kecukupan 7079\% AKG, kurang jika < 90\% AKG, cukup jika kecukupan 90-119\% $\mathrm{AKG}$, dan lebih jika kecukupan $\geq$ $120 \%$ AKG.

Status gizi siswa dianalisis menggunakan software anthroplus 2007 dengan indikator IMT/U dan LILA. Status gizi dengan IMT/U dikategorikan menurut WHO (2007) menjadi kurus (-3 $\leq \mathrm{z} \leq-2)$, normal ($2 \leq \mathrm{z} \leq+1)$, gemuk $(+1 \leq \mathrm{z} \leq+2)$, dan obese $(z>+2)$, sedangkan cut off point untuk pengukuran LILA adalah gizi baik jika >85\%; gizi kurang 70,1-84,9\%; dan gizi buruk jika $<70 \%$.

Data hasil prestasi belajar siswa dianalisis dengan cara dijumlah dan dirata-ratakan sehingga diperoleh hasil akhir yang dikategorikan menjadi sangat baik, baik, cukup, dan kurang. Sangat baik jika hasil berkisar antara 80-100, baik jika 70-79, cukup jika 60-69, dan kurang jika 50-59 (Umardani, 2011). 


\section{HASIL DAN PEMBAHASAN}

\section{Karakteristik Subyek}

\section{Usia dan Pendidikan}

Subyek pada penelitian ini adalah siswa sekolah dasar (SD) kelas 5. Rentang usia siswa adalah 10 sampai 13 tahun. Rata-rata siswa berusia 11,52 $\pm 0,67$ tahun. Pada wilayah pantai sebagian besar siswa berusia 11 tahun sedangkan pada wilayah bukan pantai siswa banyak yang berusia 11 dan 12 tahun.

\section{Uang Saku}

Uang saku siswa berkisar antara Rp 3.000,00-Rp 20.000,00 dan dikategorikan menjadi $\leq \mathrm{Rp}$ 5.000,00; Rp 6.000,00-10.000,00; dan $\geq$ Rp 10.000,00. Sebagian besar subyek $(72,22 \%)$ memiliki kisaran uang saku $\leq \mathrm{Rp} 5.000,00$. Rata-rata uang saku subyek di daerah pantai jauh lebih tinggi $(8.259 \pm 5.417,87)$ dibandingkan daerah bukan pantai (3.944 $\pm 1.809,87)$. Terdapat perbedaan yang nyata antara uang saku siswa di daerah pantai dan bukan pantai $(\mathrm{p}<0,005)$.

Uang saku subyek daerah pantai lebih tinggi dibanding daerah bukan pantai, meskipun tingkat pendapatan orang tua keduanya relatif sama. Hal itu disebabkan karena perbedaan alokasi penggunaan uang dalam pembelian makan. Uang saku subyek daerah bukan pantai lebih sedikit karena hanya untuk membeli makanan ringan. Berbeda halnya dengan daerah pantai uang sakunya diberikan untuk membeli seluruh kebutuhan makan subyek dalam sehari, baik makan berat maupun ringan, karena orang tuanya tidak menyediakan makan berat di rumah, sehingga anak harus membeli makan sendiri di luar rumah ketika waktu makan tiba. Karena itu, uang saku subyek di daerah pantai dan bukan pantai menjadi relatif sama jika yang diperhitungkan dengan alokasinya.

\section{Usia Menarche}

Usia 10-12 tahun bagi perempuan dan 12-14 tahun bagi laki-laki adalah masa anak usia sekolah membutuhkan asupan gizi yang lebih banyak, tidak hanya untuk pertumbuhan fisik tetapi juga untuk pematangan organ reproduksi sebagai persiapan memasuki masa dewasa. Pada fase tersebut anak telah mencapai masa pubertas, pada perempuan ditandai dengan menarche (usia awal seorang perempuan mengalami menstruasi). Lemak tubuh dan protein merupakan 
zat gizi yang mempengaruhi pembentukan dan kerja hormon steroid yang berpengaruh pada pematangan organ reproduksi, sehingga komposisinya berhubungan dengan kecepatan menarche seseorang (Indrawani dan Sudiarti, 2007).

Subyek perempuan pada penelitian ini $12,5 \%$ telah mengalami menarche pada usia 12 tahun. Kondisi ini berkaitan dengan komposisi lemak tubuh dan proteinnya yang tercermin dalam LILA.

\section{Pengetahuan Gizi}

Pengetahuan gizi subyek sebagian besar $(85,19 \%)$ berada pada kategori sedang dengan skor rata-rata $7,06 \pm 1,07$. Rata-rata pengetahuan gizi siswa di wilayah pantai sedikit lebih tinggi $(7,19 \pm 1,00)$ dibanding siswa di wilayah bukan pantai $(6,93$ $\pm 1,24)$. Tidak terdapat perbedaan yang nyata antara pengetahuan gizi siswa di wilayah pantai dan bukan pantai $(p>0,05)$.

Pengetahuan gizi sebagai hasil dari proses pendidikan gizi selalu dimaksudkan agar seseorang mengubah perilaku konsumsi gizi menuju perilaku yang lebih baik. Namun, memiliki pengetahuan gizi tidak berarti seseorang mau mengubah kebiasaan makannya karena dalam proses pembentukan kebiasaan makan tidak hanya dipengaruhi oleh pengetahuan gizi tetapi juga faktor faktor lain seperti misalnya preferensi, faktor sosial budaya, dan ekonomi (Khomsan, 2000).

\section{Karakteristik Keluarga Subyek}

Besar Keluarga

Besar keluarga subyek di wilayah pantai dan bukan pantai tidak berbeda nyata $(p>0,05)$. Sebagian besar subyek memiliki besar keluarga sedang (anggota keluarga yang tinggal dalam satu rumah berjumlah 5-6 orang), baik di wilayah pantai maupun bukan pantai. Menurut Sanjur (1997), jumlah keluarga mempengaruhi jumlah pangan yang dikonsumsi dalam keluarga tersebut.

\section{Pendidikan Orang Tua}

Tingkat pendidikan orang tua subyek, baik ayah maupun ibu tidak berbeda nyata di kedua daerah $(p>0,05)$. Sebagian besar tingkat pendidikan ayah dan ibu subyek adalah SD. Pendidikan tertinggi 
orang tua subyek di kedua wilayah adalah SMA dan masih terdapat beberapa ibu subyek di wilayah pantai yang tidak sekolah.

\section{Pendapatan Orang Tua}

Pekerjaan ayah subyek di daerah pantai sebagian besar adalah nelayan $(48,15 \%)$, sedangkan di daerah bukan pantai adalah buruh $(48,15 \%)$. Pendapatan orang tua subyek (per bulan atau per hari?) berkisar $\mathrm{Rp} \quad 300.000,00-\quad \mathrm{Rp}$ 3.000.000,00 dan tidak ada perbedaan yang nyata antara pendapatan orang tua subyek di kedua daerah $(p>0,05)$. Secara keseluruhan sebagian besar orang tua subyek memiliki pendapatan $<1$ juta. Tingkat pendapatan orang tua berpengaruh terhadap daya beli keluarga, sehingga dapat mempengaruhi tingkat konsumsi contoh (Widiamurti, 1998).

\section{Kebiasaan Konsumsi Ikan Laut}

Jenis, Jumlah, dan Frekuensi Konsumsi

Konsumsi jenis ikan laut subyek daerah pantai lebih beragam.

Di daerah bukan pantai konsumsi ikan laut hanya pada beberapa jenis ikan saja seperti tongkol, cumi, bawal, gabus, teri, rebon, dan cue.
Sementara di daerah pantai, kurang lebih sekitar 17 jenis ikan laut sering dikonsumsi.

Dalam penelitian ini, diketahui siswa di daerah pantai ratarata mengonsumsi ikan laut 26,23 g/hari, sedangkan daerah bukan pantai sebesar $12,70 \mathrm{~g} / \mathrm{hari}$. Konsumsi ikan laut di daerah pantai lebih besar dibanding bukan pantai $(\mathrm{p}<0,05)$. Jumlah tersebut lebih kecil dibanding hasil penelitian Oktari (2008), bahwa tingkat konsumsi ikan anak sekolah dasar keluarga nelayan sebesar 46,8 g/hari, sedangkan anak keluarga non nelayan 28,7 g/hari. Konsumsi ikan subyek dalam sehari belum memenuhi standar yang dianjurkan oleh prinsip tumpeng gizi seimbang yaitu 2-3 porsi per hari untuk lauk hewani atau 100-150 g untuk ikan.

Frekuensi konsumsi ikan laut subyek di daerah pantai maupun bukan pantai sebagian besar berada dalam kategori sangat sering. Ratarata frekuensi konsumsi ikan laut subyek di daerah pantai adalah 9,97 $\pm 5,40 \mathrm{kali} /$ minggu sedangkan di daerah bukan pantai adalah 5,17 \pm 4,47 kali/ minggu. Secara keseluruhan, rata-rata frekuensi 
konsumsi ikan laut subyek adalah $7,57 \pm 5,48$. Terdapat perbedaan yang nyata antara frekuensi konsumsi ikan laut subyek di daerah pantai dan bukan pantai $(\mathrm{p}<0,05)$. Faktor yang menyebabkan perbedaan konsumsi keduanya kemungkinan terletak pada ketersediaan ikan laut di lingkungannya.

\section{Preferensi dan Persepsi}

Secara keseluruhan subyek pada kedua wilayah menyukai ikan laut. Sebagian besar alasan dari subyek menyukai ikan laut adalah karena rasanya yang enak $(53,70 \%)$ dan bergizi (44,45\%). Tidak ada subyek yang memberikan alasan menyukai ikan laut karena harganya murah meskipun subyek di daerah pantai dapat memperolehnya dengan cara langsung menangkapnya. Sebagian besar subyek mengonsumsi ikan laut 1-6 kali per minggu $(51,85 \%)$ dan setiap hari $(31,48 \%)$. Konsumsi ikan setiap hari banyak terjadi pada siswa daerah pantai (44,45\%), sedangkan jumlah siswa yang jarang mengonsumsi ikan di daerah bukan pantai lebih besar (29,63\%). Dengan demikian frekuensi konsumsi ikan laut subyek dapat dikategorikan sering. Tabel 17 berikut ini menyajikan preferensi subyek terhadap ikan laut.

Tabel 1. Preferensi dan alasan subyek mengonsumsi ikan

\begin{tabular}{|c|c|c|c|c|c|c|}
\hline \multirow[t]{3}{*}{ Variabel } & \multicolumn{4}{|c|}{ Wilayah } & \multicolumn{2}{|c|}{ Total } \\
\hline & \multicolumn{2}{|c|}{ Pantai } & \multicolumn{2}{|c|}{ Bukan Pantai } & \multirow[b]{2}{*}{$\mathbf{n}$} & \multirow[b]{2}{*}{$\%$} \\
\hline & n & $\%$ & n & $\%$ & & \\
\hline \multicolumn{7}{|l|}{ Preferensi } \\
\hline Tidak Suka & 0 & 0,00 & 0 & 0,00 & 0 & 0,00 \\
\hline Suka & 27 & 100,00 & 27 & 100,00 & 54 & 100,00 \\
\hline Total & 27 & 100,00 & 27 & 100,00 & 54 & 100,00 \\
\hline \multicolumn{7}{|l|}{ Frekuensi } \\
\hline $1-3 x /$ bulan & 1 & 3,70 & 8 & 29,63 & 9 & 16,67 \\
\hline $1-6 x / m i n g g u$ & 14 & 51,85 & 14 & 51,85 & 28 & 51,85 \\
\hline $1 \mathrm{x} /$ hari & 12 & 44,45 & 5 & 18,52 & 17 & 31,48 \\
\hline Total & 27 & 100,00 & 27 & 100,00 & 54 & 100,00 \\
\hline \multicolumn{7}{|l|}{ Olahan } \\
\hline Digoreng & 10 & 37,04 & 16 & 59,26 & 26 & 48,15 \\
\hline Dibakar & 4 & 14,82 & 1 & 3,70 & 5 & 9,27 \\
\hline Dipepes & 0 & 0,00 & 6 & 22,22 & 6 & 11,11 \\
\hline Dipindang & 9 & 33,32 & 4 & 14,82 & 13 & 24,07 \\
\hline Semua & 4 & 14,82 & 0 & 0,00 & 4 & 7,40 \\
\hline Total & 27 & 100,00 & 27 & 100,00 & 54 & 100,00 \\
\hline
\end{tabular}

Ikan laut yang dikonsumsi jenisnya (tongkol, cumi, kembung, subyek daerah pantai lebih banyak petek, teri, udang, rebon) dibanding 
di daerah bukan pantai (tongkol, cumi, bawal, dan teri). Ikan teri merupakan jenis ikan laut yang banyak dikonsumsi baik di daerah pantai $(25,6 \%)$ maupun bukan pantai $(35,7 \%)$. Perbedaannya ikan teri yang dikonsumsi di daerah pantai adalah ikannya masih segar, sedangkan di daerah bukan pantai ikannya telah dikeringkan dan diasinkan.

Olahan ikan laut yang disukai subyek adalah digoreng (48,15\%), dipindang $\quad(24,07 \%), \quad$ dipepes $(11,11 \%)$, dibakar $(9,27 \%)$, dan semua bentuk olahan $(7,40 \%)$. Olahan dengan digoreng lebih banyak disukai subyek di kedua daerah, karena rasa ikan menjadi lebih gurih dengan adanya penambahan lemak dalam minyak untuk menggoreng.

\section{Tingkat Kecukupan Energi dan \\ Protein}

\section{Tingkat Kecukupan Energi (TKE)}

Tingkat kecukupan energi sebagai hasil kebiasaan makan berpengaruh terhadap status gizi dan status kesehatan. Rata-rata tingkat kecukupan energi subyek adalah $95,70 \pm 35,78 \%$. Rata-rata tingkat kecukupan energi subyek di daerah pantai lebih tinggi $(103,44 \pm$ $35,17 \%$ ) dibanding daerah bukan pantai $(87,96 \pm 35,32 \%)$. Di daerah pantai sebagian besar memiliki tingkat kecukupan energi dalam kategori cukup sedangkan daerah bukan pantai sebagian besarnya dalam kategori defisit berat. Ratarata TKE di daerah bukan pantai dalam kategori kurang, sedangkan di daerah pantai berada dalam kategori cukup. Terdapat perbedaan yang signifikan antara tingkat kecukupan energi di daerah pantai dan bukan pantai $(\mathrm{p}<0,05)$. Gambar 2 berikut ini menyajikan sebaran TKE subyek di kedua wilayah.

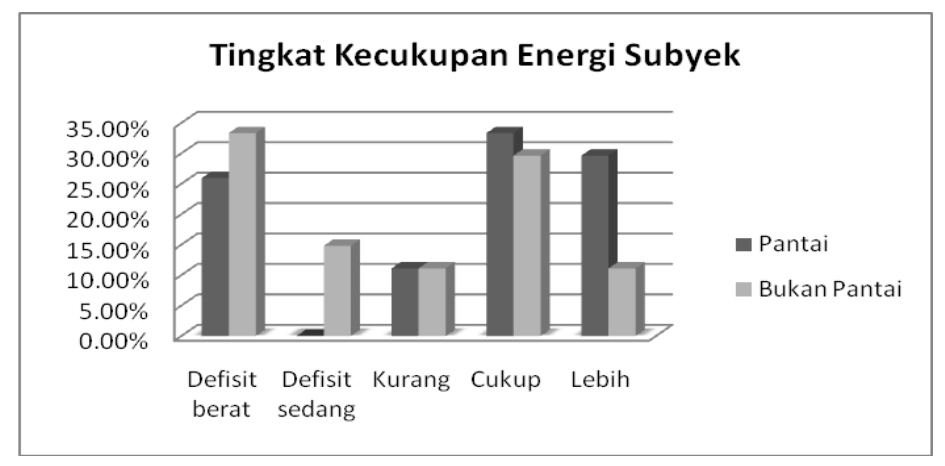

Gambar 1. Tingkat kecukupan energi subyek di kedua wilayah 


\section{Tingkat Kecukupan Protein (TKP)}

Perbedaan

kebiasaan

konsumsi ikan laut mempengaruhi perbedaan tingkat kecukupan protein. Rata-rata tingkat kecukupan protein contoh adalah 89,13 $\pm 37,64 \%$, atau dalam kategori kurang menurut Depkes (1996). Rata-rata tingkat kecukupan protein di daerah pantai lebih tinggi $(102,16 \pm 38,79 \%)$ dibanding daerah bukan pantai $(76,09 \pm 32,11 \%) . \quad$ Tingkat kecukupan protein rata-rata di daerah pantai sudah dalam kategori cukup sedangkan di daerah bukan pantai masih dalam kategori defisit tingkat sedang. Sebagian besar subyek di daerah pantai $(37,04 \%)$ memiliki kategori tingkat kecukupan protein yang lebih sedangkan di daerah bukan pantai sebagian besar subyek $(55,56 \%)$ memiliki kategori tingkat kecukupan protein defisit berat. Perbedaan yang signifikan terjadi antara tingkat kecukupan protein subyek di daerah pantai dan bukan pantai $(\mathrm{p}<0,05)$. Gambar 2 berikut ini menunjukkan sebaran TKP subyek pada kedua wilayah.

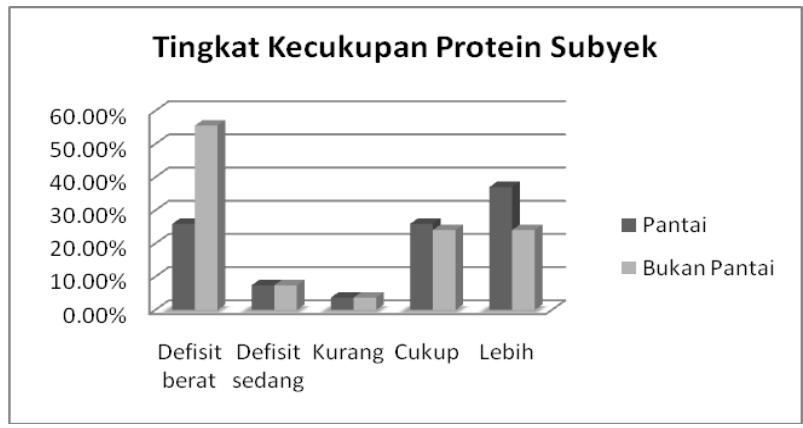

Gambar 2. Tingkat kecukupan protein subyek di kedua wilayah

\section{Kontribusi Protein Ikan Laut}

Kontribusi protein ikan laut berbeda nyata di kedua daerah $(p<0,05)$. Konsumsi ikan laut di daerah pantai rata-rata per hari adalah 26,23 g dengan kontribusi protein sebesar $7,37 \mathrm{~g}$, sedangkan di daerah bukan pantai hanya sebesar 12,70 g atau dengan kontribusi protein 3,48 g. Kontribusi protein ikan laut di daerah pantai lebih besar $(15,58 \%)$ dibanding daerah bukan pantai $(10,26 \%)$.

Protein yang berasal dari ikan menyumbang $7,75 \mathrm{~g}$ dalam rata-rata konsumsi protein sehari subyek di daerah pantai dan 4,18 g/hari untuk di daerah bukan pantai. Jumlah 
tersebut lebih kecil dari temuan Oktari (2008) yang menyatakan bahwa sumbangan protein dari ikan dalam konsumsi protein sehari pada anak sekolah dasar keluarga nelayan sebesar $9 \mathrm{~g}$ dan 4,7 g untuk anak keluarga non nelayan.

\section{Status Gizi}

\section{Status Gizi IMT/U}

Status gizi subyek baik di daerah pantai maupun bukan pantai rata-rata berada dalam kategori normal. Sebagian besar subyek baik di daerah pantai $(66,67 \%)$ maupun bukan pantai $(92,59 \%)$ juga memiliki status gizi normal. Berdasarkan hasil uji beda independent samples t-test terdapat perbedaan yang nyata antara status gizi subyek di daerah pantai dan bukan pantai ( $\mathrm{p}<0,05)$. Perbedaan status gizi disebabkan oleh berbagai faktor, diantaranya adalah kebiasaan makan. Kebiasaan makan yang berbeda menyebabkan tingkat kecukupan energi dan berbagai zat gizi lain berbeda, yang pada akhirnya menjadikan perbedaan status gizinya. Gambar 7 menyajikan hasil pengkategorian status gizi berdasarkan indikator TB/U.

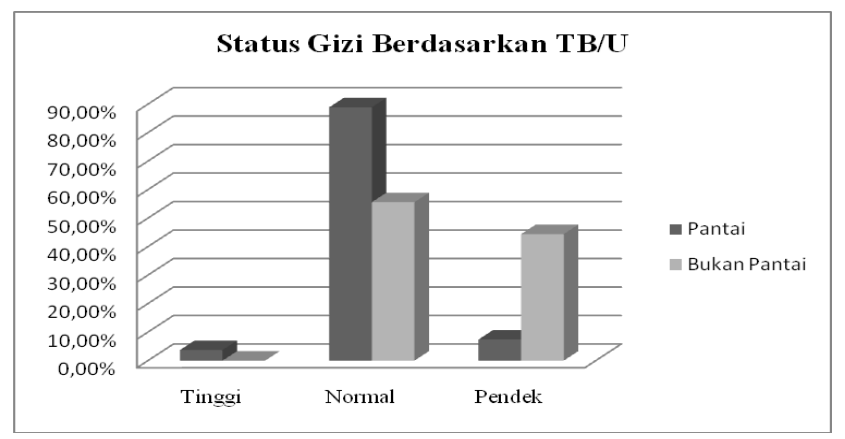

Gambar 3. Status gizi siswa berdasar TB/U

Status Gizi LILA

Status gizi LILA subyek di kedua daerah tidak memperlihatkan perbedaan yang nyata $(\mathrm{p}>0,05)$. Rata-rata status gizi subyek dengan indikator LILA berada dalam kategori status gizi baik $(89 \pm$ $14,49 \%)$, di wilayah pantai (92 \pm $16,29 \%)$ maupun bukan pantai (87 \pm 12,29\%). Sebagian besar subyek di daerah pantai memiliki status gizi baik $(51,85 \%)$ sedangkan daerah bukan pantai kategori gizi kurang $(55,56 \%) \quad$ (Gambar

4). 


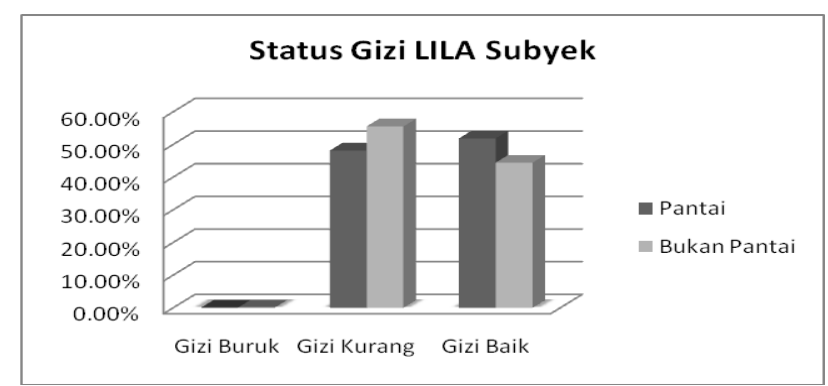

Gambar 4 Kategori status gizi subyek berdasar LILA

Kondisi LILA pada $(\mathrm{p}<0,05)$ antara status menarche perempuan usia pubertas dapat menjadi indikator kecepatan kematangan organ reproduksinya karena LILA mencerminkan kondisi protein dan lemak tubuh. Menurut Buyken et al. (2009), protein dan lemak merupakan zat gizi yang berperan dalam pembentukan dan kerja hormon steroid yang berpengaruh organ reproduksi. Hal tersebut dapat dilihat dengan mengetahui masa menarche anak perempuan dikaitkan dengan kondisi LILA. Subyek perempuan dalam penelitian ini berada dalam masa pubertas sehingga dilakukan uji hubungan antara kondisi LILA dengan status menarche. Terdapat hubungan hubungan yang signifikan subyek dengan besar LILA.

\section{Prestasi Belajar}

Nilai rata-rata prestasi belajar sebesar $69,93 \pm 7,84 \%$. Nilai ratarata di daerah pantai lebih tinggi $(72,84 \pm 8,48 \%)$ dibanding daerah bukan pantai $(67,02 \pm 5,98 \%)$. Prestasi belajar subyek daerah pantai sebagian besar berada dalam kategori baik (37,04\%), sedangkan daerah bukan pantai berada dalam kategori cukup (59,26\%). Masih terdapat beberapa subyek yang memiliki prestasi belajar kurang di daerah pantai $(7,41 \%)$, maupun bukan pantai (3,70\%). Terdapat perbedaan yang nyata antara prestasi belajar subyek di daerah pantai dan bukan pantai $(\mathrm{p}<\quad 0,05) \quad($ Gambar

$5)$.

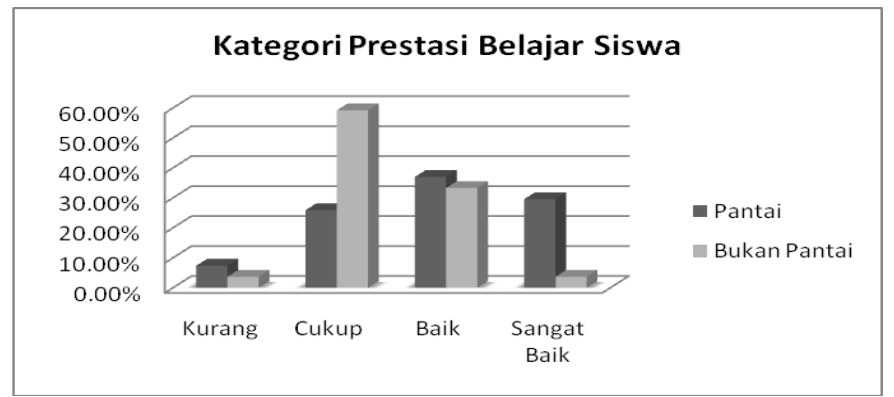

Gambar 5 Sebaran subyek berdasarkan kategori prestasi belajar 
Hubungan Kebiasaan Konsumsi

Ikan Laut Siswa dengan Tingkat

Konsumsi Energi dan Protein,

\section{Status Gizi, dan Prestasi Belajar}

Frekuensi konsumsi ikan laut mempunyai hubungan yang signifikan terhadap tingkat konsumsi energi $\quad(p=0,002 ; \quad r=0,419) \quad$ dan protein $\quad(\mathrm{p}=0,001 ; \quad \mathrm{r}=0,426)$, sedangkan jumlah konsumsi ikan laut berhubungan positif dengan tingkat kecukupan protein $(\mathrm{p}=0,001$; $\mathrm{r}=0,456$ ). Tingkat kecukupan energi (TKE) berhubungan nyata dengan status gizi IMT/U $(p=0,000 ; \quad r=-$ 0,659)dan LILA ( $\mathrm{p}=0,000 ; \mathrm{r}=-0,554)$. Tingkat kecukupan energi (TKE) juga memiliki hubungan yang signifikan dengan prestasi belajar $(\mathrm{p}=0,012 ; \quad \mathrm{r}=0,340) . \quad$ Tingkat kecukupan protein (TKP) berhubungan positif dengan status gizi IMT/U ( $\mathrm{p}=0,000 ;-0,558)$ dan LILA $(p=0,001 ; r=-0,430)$. Status gizi IMT/U memiliki korelasi dengan LILA $(p=0,000 ; r=0,914)$, artinya kedua indikator tersebut memberikan hasil yang sinergis dalam pengukuran status gizi. Frekuensi dan jumlah konsumsi ikan laut tidak memperlihatkan hubungan yang nyata dengan status gizi dan prestasi belajar.

\section{KESIMPULAN}

Terdapat perbedaan yang nyata pada jumlah dan frekuensi konsumsi ikan laut, tingkat kecukupan energi dan protein, status gizi IMT/U, dan prestasi belajar subyek di daerah pantai dan bukan pantai. Frekuensi konsumsi ikan laut memiliki hubungan yang signifikan terhadap tingkat konsumsi energi dan protein. Frekuensi konsumsi ikan laut berhubungan nyata dengan jumlahnya, dan dengan tingkat kecukupan protein. Tingkat kecukupan energi memiliki hubungan yang signifikan dengan prestasi belajar dan status gizi IMT/U serta LILA. Tingkat kecukupan protein (TKP) juga berhubungan secara nyata dengan status gizi IMT/U dan LILA.

\section{DAFTAR PUSTAKA}

Almatsier S. 2004. Prinsip Dasar Ilmu Gizi. Gramedia Pustaka Utama. Jakarta

Afrianto dan Liviawaty. 1989. Pengawetan dan Pengolahan Ikan. Kanisius. Yogyakarta.

Buyken AE, Karaolis-Danckert N, Remer T. 2009. Association of prapubertal body composition in healthy girls and boys with the timing of early and late pubertal markers. American 
Journal of Clinical Nutrition 89: 221-230

Camelia LS. 2002. Konsumsi ikan dan faktor yang mempengaruhinya pada remaja di SMUN 9 Bandung. Skripsi. Departemen Gizi Masyarakat dan Sumberdaya Keluarga. Fakultas Pertanian. Institut Pertanian Bogor.

Departemen Kesehatan. 1996. Pedoman Praktis Pemantauan Gizi Orang Dewasa. Depkes. Jakarta

Krauss-Etschmann S, Shadid R, Campoy C, Hoster E, Demmelmair H, Jiménez M, Gil A, Rivero M, Veszprémi B, Decsi T, Koletzko BV; Nutrition and Health Lifestyle (NUHEAL) Study Group.. 2007. Effects of fish-oil and folate supplementation of pregnant women on maternal and fetal plasma concentration of docosahexaenoic acid and eicosaepentaenoic acid: a European randomized multicenter trial. American Journal Clinical Nutrition 85: 1392-140

Fernandez E, Chatenoud L, La Vecchia C, Negri E, and Franceschi S.1999. Fish consumption and cancer risk. American Journal of Clinical Nutrition 70: 85-90.

Indrawani dan Sudiarti. 2007. Gizi dan Kesehatan Masyarakat. Raja Grafindo Persada. Jakarta.

Khomsan A. 2000. Teknik Pengukuran Pengetahuan Gizi. Fakultas Pertanian IPB. Bogor.

Nurk E, Drevon CA, Refsum H, Solvoll $K$, Vollset SE, Nygård $O$, Nygaard HA, Engedal K, Tell GS, Smith AD. 2007. Cognitive performance among the elderly and dietary fish intake: the Hordaland health study. American Journal of Clinical Nutrition 86: 1470-1478

Oktari RN. 2008. Konsumsi ikan anak usia sekolah pada keluarga nelayan dan non nelayan berdasarkan keadaan sosial ekonomi. Skripsi. Program Studi Gizi Masyarakat dan Sumberdaya Keluarga. Fakultas Pertanian. Institut Pertanian Bogor.

Oken E, Østerdal ML, Gillman MW, Knudsen VK, Halldorsson TI, Strøm M, Bellinger DC, HaddersAlgra M, Michaelsen KF, and Olsen SF. 2008. Association of maternal fish intake during pregnancy and breastfeeding duration with attainment of developmental milestones in early childhood: a study from the Danish National Birth Cohort. American Journal of Clinical Nutrition 88: 789-796

Sanjur D. 1997. Assessing Food Consumption. Cornell University. New York.

Soekarti M, Soetardjo S, Almatsier S. 2011. Gizi Seimbang Dalam Daur Kehidupan. Gramedia Pustaka Utama. Jakarta.

Suhartini dan Hidayat. 2005. Olahan Ikan Segar. Trubus Agrisarana. Surabaya.

Suryabrata S. 2005. Psikologi Pendidikan. Raja Grafindo Perkasa. Jakarta.

Syah. 2010. Psikologi Pendidikan dengan Pendekatan Baru. Remaja Rosdakarya. Bandung.

Umardani MR. 2011. Kebiasaan jajan, aktivitas fisik, status gizi dan kesehatan serta hubungannya dengan prestasi belajar siswa sekolah dasar di Kota Bogor. Skripsi. Bogor: Departemen Gizi Masyarakat. Fakultas Ekologi Manusia. Institut Pertanian Bogor.

Verbeke W and Vackier I. 2005. Individual determinants of fish consumption: application of the theory of planned behavior. Appetite 44: 67-82

Vizuete AA, Robles F, Rodríguez-Rodríguez E, López-Sobaler AM, and Ortega RM.2010. Association between food and nutrient intakes and cognitive capacityin group of institutionalized elderly people. European Journal of Nutrition. 49: 293-300

World Health Organization. 2007. BMI for age (5-19 years). http://www.who.int/growthref/who 2007bmi-for-age/en/index.html Diakses tanggal 10 Mei 2012).

Widiamurti MN. 1998. Studi pola konsumsi pangan dan status gizi masyarakat Arfak di daerah dataran tinggi dan dataran rendah Kabupaten Manokwari Irian Jaya. Tesis. Program Pascasarjana Institut Pertanian Bogor. 